\title{
On the Issue of the Efficiency of Economic Education in the Globalized World
}

Tatiana S. Tsytskun*

Kuban State University 36 Communist Str., Novorossiysk, 353900, Russia

Received 19.12.2014, received in revised form 04.02.2015, accepted 21.05.2015

The article studies the problems of efficiency of economic education in the globalized world. The author focuses on the most pronounced tendencies that characterize the specificity of reforms in the system of economic education in modern Russia. The main directions of improving the efficiency of those fields of the humanities, which create the conditions for economic modernization, are discussed.

Keywords: economic education, efficiency, economic viability, globalized world, globalization processes, transnational sector of economics.

Research area: philosophy.

The relevance of studying the challenges and peculiarities of modern economic education with consideration of information technology is that the results of socio-philosophical analysis can be used as a general theoretical framework for applied research with direct practical relevance. Globalization process in the $21^{\text {st }}$ century occurs in the polarized world, in terms of economic opportunities and economic potential, largely due to the imperfect system of economic education, which lags far behind the world's needs.

Economic education has a number of features. First, the solution of many financial problems of the population depends not only on the specific economic reality, but also on the methodology of its study, which in today's global world is set at the level of educational sphere.
Second, globalization processes in the field of education that occur in the contemporary world, can be seen as part of a long historical transition from the era of internationalization of economic life to the formation of transnational human community. Third, education and economy in the globalized world are not only fundamental social institutions, but also a special form of social consciousness with a powerful integration basis.

Synthesizing the leading concepts of economic education in the academic literature, and taking into account the phenomena brought to life by globalization, we can say that global economic education has the following features:

- the emergence of the global financial economy, independent of the global financial and monetary system, with a

(C) Siberian Federal University. All rights reserved

* Corresponding author E-mail address:nvrsk@mail.ru 
decisive impact on the state and structure of economic education;

- the transnational sector of economy not only binds advanced management systems by means of up-to-date communications technology, but also brings to life new epistemological mechanisms that will be most in demand, particularly in economic education;

- global economic education can not be effective without modern information technologies with general rules and principles of operation, etc.

- the penetration of the knowledge economy based on the ever-widening process of turning science into the main productive force of modern society with far-reaching consequences for all aspects of their life, in various forms into all the pores of economic life;

- training of a high-skilled specialist for the post-industrial economy promotes the intellectualization of labour and the increase in the share of creativity in them, anticipating the transformation of the economic man into the creative man;

- economic education encourages regional integration in cases when globalization tendencies encounter the unwillingness of some countries to make concessions and losses that turn into benefits and profits for others.

- the integration processes in global education imply an economic component, which may be based, in particular, on economic education, optimizing all the vectors of development of the educational field;

- economic education in all its forms is nothing more but a somewhat optimal form of promoting social institutions in the direction of globalization;
- global economic education, on the one hand, optimizes fruitful international competition and on the other hand, coordination of macroeconomic policies of national states;

- there is a directly proportional relationship between effective economic education and maturity of market mechanisms that actualizes the problem of investments in particular, especially demanded university qualifications;

- efficient economic education contributes to the development of tools and mechanisms to overcome national egoism of the "golden billion" countries while maintaining their productive capacity;

- modern economic education is an important step towards the elimination of economic backwardness of most of the peoples of the modern world, because it gives the opportunity to develop a new cohort of highly qualified specialists in the field of the national economy.

The socio-cultural significance of civilizational processes, which have begun under the influence of various factors of the transformation, is associated with the peculiarities of the current dynamics of the world, in particular, the deepening of economic globalization and the debates about its meaning and direction. [3]

The scientific community has been actively developing a new categorical apparatus of global studies, but the analysis of the new global phenomena involves consideration of the economic factor, which is closely associated with modern information technologies. The following new scientific categories are introduced in everyday life: economic borders, inter-clan division of labor, system of global responsibilities, internationalized reproductive nuclei, world income, geoeconomic atlas of the world, geoeconomic high technologies, 
geofinance, geoculture, ethnoeconomic systems, geoeconomic war, etc.

An institutional approach to the measurement of economic development includes not only traditional indicators that determine the state and development of natural, climatic and geographical potentials, tangible capital (quantity and quality of land, volume, structure, state and effectiveness of fixed assets, etc.) and financial capital, but also intangible capital (intellectual property, information), scientific potential, market environment (level of competition, market infrastructure, etc.), global factors and conditions (the state of the world economy, globalization of the economy, external threats, etc.).

Approaches to the contemporary globalregional economic world order, as well as its assessment are ambiguous. Neo-liberals support free trade and economic rationalism. Skeptics, neo-realists, on the contrary, criticize globalization processes, reacting to the frustration of the people of individual regions, which are suffering from the increasing unemployment and economic inequality. However, the challenges associated with the economic aspects of globalization and their impact on the socio-economic situation in specific regions of the world, are now in the focus of attention of representatives of both national and international public thoughts.

The information society generated by the mind, has put the human in the deadlocks of contradictions and problems, many of which are related to the global world economy. In turn, the solution of many material problems depends on the specific economic reality, and the methods of its study.

The global economy as a complete system, as the final result of economic globalization, is still a distant prospect, although this phenomenon already at the present stage gives the real content to the objective process of world development. In the most common form, globalization processes that occur in the contemporary world can be considered primarily as part of a long historical transition from the era of the internationalization of economic, political and cultural life with prevailing relationships between the selfdeveloping countries, to globalization, when a new, transnational, more complex level of human community with its own laws, driving forces and mechanisms of regulation is formed.

To understand the characteristics of the study of economic processes better, one should consider when the first theories of economic behaviour appeared. Since the days of Adam Smith to the present day, most economic theories and mathematical models, despite their extreme complexity, contain an extremely primitive model of the economic man as a subject, who takes economic decisions, with the following main characteristics:

1) he operates in a competitive market that requires his minimum relationship with other economic people. Others are his competitors;

2) he is rational in terms of decision-making mechanisms, capable of setting objectives, achieving them gradually, calculating the costs to choose the means to achieve the objective;

3) he has complete information about the situation in which he acts;

4) he is selfish, reaching out for the maximum benefit.

It is these assumptions that result in economic behaviour seen as an area free from all human. As if people doing business, playing on the stock exchange, and shopping are not the same people moved by very diverse incentives: the desire to be safe, vanity, passion, etc.

Supporters of the anthropocentric economy have been always in the minority, and the public consciousness was clearly imposed with an idea that the economy is a field in which the 
main motive of people and organizations is to maximize their profits regardless of exactly what kind of people and organizations they are, in which country they live and which worldviews they share.

During the study of economic processes, especially the period of globalization, it is important to adhere to the following methodological principles of social dialectics: 1) to find contradictions that are the source of the studied economic phenomena and processes; 2) to identify the causes and regular links of their development (the principle of social determinism); 3) to proceed from the fact that the laws of development of any social phenomena, including economic, do not function with mathematical accuracy, but rather as the tendencies of development of these phenomena and are largely probabilistic; 4) to take into account the content and direction of activity of the subjects of socioeconomic processes and their influence on these processes, in accordance with their interests.

During the study of the phenomena of economic life, the so-called cause-effect models are implemented. They help to identify the objective cause-effect relationships and interdependencies between economic phenomena, one causing another, and the emergence of their new properties. However, these models do not always allow to make conclusions about the phenomenon under study as a whole because, exposing its objective aspects, they do not capture the subjective factors connected with minds of people whose actions determine the content and focus of all social phenomena and processes. Economists overcome this difficulty as follows: during the analysis of the processes taking place in the whole society, i.e. at the macro level, they use the cause-effect models revealing objective factors of activity and behaviour, and during the analysis of the processes taking place in some regions, i.e. at the micro level, along with the cause-effect models they use cognitive models of interaction between small systems, which allow to identify motives, beliefs and goals of economic actors.

Highly efficient economic education involves the implementation of the wave dynamics model reproducing the undulating nature of the economy functioning, depending on economic conditions. The idea of such nature of the economy development was scientifically substantiated by a famous Russian scientist N.D. Kondrat'ev, who revealed, in particular, the existence of "long waves" in its development, depending on the mass introduction of new techniques and technologies into production, structural changes due to the emergence of new sectors of the economy, as well as various political factors and social unrest [2]. The lack of reference to such experience results in the situation when students often do not have a strategic vision of economic processes of modernity.

The formation of the global economy poses a question of the relationship between the concepts of "organization", "development" and the basic synergetic concept of "self-organization". Selforganization refers to the process of establishing order in the system solely due to cooperative actions and relationships of its components and in accordance with its previous history, leading to a change in its spatial, temporal or functional structure [5, p. 17].

In closed systems entropy increases gradually, which can be stopped by interacting of the system with the environment. That is why it can be argued that absolutely closed (as well as completely open) systems do not exist. For example, in countries with a totalitarian regime, economic life is subject to strong government regulation and control, i.e. it is governed by the system external to the market.

Entropy can not only destroy the economic system, but also bring it to a new level of self- 
organization. For example, after World War II the defeated Germany showed "economic miracle", unlike the victorious countries that showed much worse results.

During the study of the economy of modern Russia, it is also important to consider that the chaos should not be understood as a state of absolute uncertainty of the system development. It is perceived this way because it is difficult to determine which of the many self-organizing structures emerging in the old socio-economic system will becoming the controlling one, which conditions the formation and replacement of one structures by another and the development of functional relationships between them.

For socio-economic systems, this state is characterized by the transition to the critical ratio of the costs of labour, materials, energy and raw materials required for the expansion of production of goods and maintenance of the state of simple reproduction of the means of production. From that moment, the avalanche mismatching of functional relationships between all elements of the socioeconomic system begins. Such development of the process can be called a self-developing chaos, and we observe some signs of such development of the modern economy in some regions of the global world. With the development of the chaos, the state remains integrated in its form, but by the content it is made of the parts not related or loosely connected by functional relationships, i.e. it is converted into a simple summary of its parts (regions, republics, businesses, political parties, etc.).

With regard to the socio-economic processes, it is not only the state that acts as a self-organizing system, but also employees of an enterprise, stock company, farm, firm. The order in the economic system, as in any natural system, is formed as a result of the orderly exposure to social systems, which are more organized and more sustainable at the moment, collapsing, moving through the chaos and replaced by a new order. It is often fraught with the formation of a self-organizing system of the shadow economy, as happened in Russia.

Each of the subjects of the global economy creates its global market, where competition has its own specific features in comparison to other similar markets. At the top levels, quality parameters of products, innovations in their production technology, design and maintenance after the acquisition are crucial. Therefore, the possibility of the market expansion in this area is almost unlimited if they are invested. The competition at the market formed by the products of the "lower level" of the global economy looks otherwise. The natural properties of oil or gas, iron or copper ore, wheat or beef, bananas or oranges are more or less the same all over the world, qualitative differences vary in a narrow range, so the main weapon in the fight for customers is price competition. The prices of such products are largely determined by the conditions of occurrence of mineral resources, soil fertility, transportation facilities, etc. The main way to expand sales in the world market in such cases is the extensive development of production and reduction of its costs. It has clear limits, since the exhaustion of the best deposits forces to switch to the development of the worst or difficult-tomine deposits, while wages tend to increase, thus undermining the competitiveness of such products to an even greater extent. All this explains why the countries with the agricultural profile or in the early stages of industrialization are in the least favourable position and most of all transnational corporations concentrate their efforts on the development of global markets of high-tech products by reducing their presence in the lower "levels" of production and trade [6 p. 180-181]. 
To fix the changes of the leading factors of the economy in the global statistics, a new system of national accounts (SNA) has been introduced. Familiar gross domestic product (GDP) was replaced by gross national income (GNI) as a central economic indicator. The current version of the SNA was formulated in the mid-1990s and entered into force since 2000. The formula "what is sold is produced" allowed to move from thinking in terms of production of a product to thinking in terms of its distribution and gaining profit [4].

The fundamental importance of entrepreneurship in the sphere of development of social production has been noted in terms of classical economic theory. The representatives of this school of economic theory were first to justify its role in the economic growth of all business sectors. The combination of the three components of the resource potential of entrepreneurship (land, labour, capital) in certain proportions, according to representatives of the classical school, helped to organize the process of production of goods required to meet human needs. The representatives of the neoclassical school of economic theory tried to explain this fact. According to their opinion, the existing list should be completed by another kind of resource: entrepreneurship or entrepreneurial skills. The presence of the entrepreneurial resource, in their view, would allow to explain the different level of efficiency of productions that seem similar at first. In determining the business sphere as an economic category it should be noted that its content differs depending on the object of the definition. The most common definition found in the literature if the definition of the business sphere of production or trade. However, the problem lied in the complexity of determining entrepreneurship as the object of analysis, which was aggravated by the reform activities that, for example, in Russia, often do not have any clearly defined strategic vector.

One of the leading economists, researchers of globalization, Mikhail Deliagin quite reasonably pointed out that "... the direct object of study of globalization itself as an independent phenomenon is the effect of the technologies (at the present stage mainly information) that have caused it and support it, on public relations understood as relations within the society and between different human societies". [1]

Therefore, according to the law, the pace, direction and type of development of the national economy depend on its past, including the structure and mechanism of its operation, the level of development achieved, the nature of the environment and the type of relationships. That is why the global world economy requires not only specific research methods, but also the special epistemological mechanisms manifested in the efficient economic education designed to create a more harmonious world economy.

\section{References}

1. Deliagin M.G. Mirovoi krizis: Obshchaia teoriia globalizatsii [The World Crisis: General Theory of Globalizaion]. $3^{\text {rd }}$ edition, revised and enlarged. Moscow: INFRA-M, 2003. p. 55.

2. Kondrat'ev N.D. Problemy ekonomicheskoi dinamiki [Problems of Economic Dynamics]. Moscow, 1989.

3. Kulagin V.M. Mir v XXI veke: Mnogopolisny balans sil ili global'ny RAKH Democratica? Gipoteza "demokraticheskogo mira" $v$ kontekste al'ternativ mirovogo razvitiia [The World in the 21 century: Multipolice Balance of Powers or Globla RAX Democratica? The Hypothesis of the "Democratic World" in the View of the Alternatives of World Development] // Sotsis. 2000. № 1. 
4. Neklessa A.I. Ordo quadro tchetverty poriadok: prishestvie postsovremennogo mira [Ordo Quadro the Fourth Order: Postmodern World] // Polis. 2000. № 6.

5. Prigozhin I., Stengers I. Poriadok iz khaosa [The Order from the Chaos]. Moscow, 1986. p. 17.

6. Shishkov Iu. Evoliutsiia mirovogo ekonomicheskogo prostransva [Evolution of the World Economic Space]. Moscow, 2006. pp. 180-181.

\section{К вопросу об эффективности \\ экономического образования \\ в глобальном мироустройстве}

Т.А. Цыцкун

Кубанский государственный университет

Россия, 353900, Новороссийск, ул. Коммунистическая, 36

В статье исследуются проблемы эффективности экономического образования в глобальном мире. Автор акиентирует внимание на наиболее выраженных тенденциях, которые характеризуют специфику реформирования системы экономического образования современной России. Освещуаются основные направления повышения эффективности тех гуманитарных дисииплин, которые создают условия для модернизации экономики.

Ключевые слова: экономическое образование, эффективность, экономическая целесообразность, глобальное мироустройство, глобализационные процессы, транснациональный сектор экономики.

Научная специальность: 09.00.00 - философские науки. 